\title{
Effectiveness of bacterial inoculation for improving grain yield and quality of chickpea
}

\author{
Muhammad Aslam Avais*, Nisar Ahmad**, Muhammad Rafique*, Muhammad Shafique, Muhammad Zaighum \\ Mushtaq**, Muhammad Afzal Zahid* and Zubair Ahmad* \\ "Pulses Research Institute, Faisalabad \\ ***Bochemistry Section, Post-Harvest Research Centre, Faisalabad
}

Abstract

Field experiments were carried out for three consecutive Rabi seasons (2011-12 to 2013-14) at Pulses Research Institute, Faisalabad to study the effect of bacterial inoculation on grain yield and quality of chickpea (desi). One variety (Pb-2008) and four advanced lines viz. D-03009, D-06002, D-06003 and D-06052 were tested with and without bacterial inoculation (Mesorhizobium ciceri, Pseudomonas spp. and Bacillus spp.). On a loamy soil (EC =

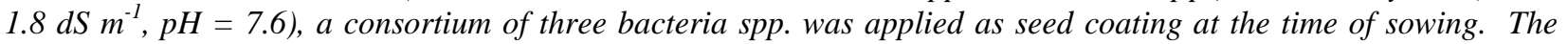
experiments were laid out in split plot design with three replications. Results showed a significant increase in nodulation (17.5\%), plant height (4.0\%), number of pods per plant (7.8\%) and grain yield (7.5\%) due to bacterial inoculation. The increase/decrease in the number of branches per plant (3.8\%), 100 grain weight (1.9\%), protein ($4.5 \%)$, carbohydrate $(0.0 \%)$, crude fiber $(2.0 \%)$ and mineral matter $(2.5 \%)$, remained statistically non-significant. The interaction among local cultivar / advanced lines and microbial inoculation was significant for improving grain yield. The advanced line D-06052 yielded with highest grains $\left(2890 \mathrm{~kg} \mathrm{ha}^{-1}\right)$ due to bacterial inoculation. Hence, it can be argued that the bacterial inoculation positively influenced the grain yield and its components without fading the quality of produce. Bacterial inoculation is recommended for better chickpea yield.

Keywords: Bacterial inoculation, chickpea, yield, protein

\section{Introduction}

Chickpea (Cicer arietinum L.) is an important pulse crop in Pakistan. During the year 2013-14, it was cultivated on an area of 949.6 thousands hectare with a total production 399.0 thousand tons and an average of $420 \mathrm{~kg}$ $\mathrm{ha}^{-1}$ (Government of Pakistan, 2014). It is a cheap source of high quality protein in the diets of millions of people in developing countries, who cannot afford animal protein for balanced nutrition. In addition to proteins, it is a good source of carbohydrates, minerals and trace elements (Huisman and Poel, 1994). Average yield of chickpea in Pakistan is usually low. Soils of Pakistan are generally deficient in nitrogen; the most important element in the metabolism of plants and protein synthesis. Its deficiency in soil usually results in low crop yield (Romdhane et al., 2008). Yield of chickpea can be improved by using seed of good varieties, balanced fertilizers, good agronomic practices and the use of efficient bacteria as biofertilizer. Crop productivity can be increased by the application of chemical, organic and biological fertilizers (Elliott and Abbott, 2003). Inoculation increases soil nitrogen along with the increase in root and shoot nitrogen (Ahmed et al., 2008). It has been reported by a number of researchers that rhizobial inoculation increases the root/ shoot length, number of pods, nodulation and yield of chickpea (Gupta and Namdeo ,1997, Sarma et al., 2009, Akhtar and Siddiqui , 2009 and Zahir et al., 2010). Field trials showed that nearly $50 \% \mathrm{~N}$ fertilizer can be saved through rhizobial inoculations with considerable increase in yield (Rewari and Nkvbr, 1988, Tilak, 1993, Ekhlas et al., 2011 and Tahir et al., 2011). The efficacy of microorganism is also affected by soil type, source and quantity of soil nutrients as well as the test crop (Bhuiyan et al., 2008, Mehboob et al., 2008, Javed and Bajwa , 2011). Rhizobium inoculation not only increases the yield but also improves the quality of produce with increases in protein, crude fiber, fat, ash and carbohydrate contents in chickpea (Aslam et al., 2010, Abdalla et al., 2013, and Singh et al., 2014).

The present study was therefore, carried out to compare the effect of microbial inoculation on the yield, nodulation and grain quality of various lines/variety of chickpea (desi gram).

\section{Materials and Methods}

Field experiments are conducted to study the effect of bacterial inoculation (Mesorhizobium ciceri, Pseudomonas spp. and Bacillus spp.) on a variety and the advanced lines of chickpea for improving the grain yield and grain quality for three consecutive years (2011-12 to 2013-14) at Pulses Research Institute, Faisalabad, Pakistan. The experimental design used was factorial (Two factors, inoculation and varieties) laid out in split plot with three replications. The plot size, plant to plant and row to row spacing was $1.2 \mathrm{~m} \times$ $4 \mathrm{~m}, 15 \mathrm{~cm}$ and $30 \mathrm{~cm}$, respectively. A variety $(\mathrm{Pb}-2008)$

\footnotetext{
*Email: nisarahmadac62@gmail.com
} 
Table 1 Effect of bacterial inoculation on the grain yield and 1000 grain weight of some advanced lines of Chickpea.

\begin{tabular}{|c|c|c|c|c|c|c|c|}
\hline \multirow[t]{2}{*}{ S. No. } & \multirow{2}{*}{$\begin{array}{l}\text { Variety/ } \\
\text { Lines }\end{array}$} & \multicolumn{3}{|c|}{ Grain yield $\left(\mathrm{kgha}^{-1}\right)$} & \multicolumn{3}{|c|}{1000 grain weight $(\mathrm{g})$} \\
\hline & & Un-inoculated & Inoculated & Mean & Un-inoculated & Inoculated & Mean \\
\hline 1 & $\mathrm{~Pb}-2008$ & $2152 \mathrm{ef}$ & $2345 \mathrm{c}$ & $2248 \mathrm{~B}$ & 223.4 & 229.0 & $226.2 \mathrm{~A}$ \\
\hline 2 & D-03009 & $1944 \mathrm{~h}$ & $2111 \mathrm{fg}$ & $2028 \mathrm{D}$ & 202.2 & 197.2 & $199.7 \mathrm{~B}$ \\
\hline 3 & D-06002 & $2012 \mathrm{gh}$ & $2269 \mathrm{cde}$ & $2140 \mathrm{C}$ & 188.5 & 196.8 & $192.7 \mathrm{~B}$ \\
\hline 4 & D-06003 & $2268 \mathrm{~cd}$ & $2181 \mathrm{def}$ & 2224 B & 191.7 & 218.0 & $205.3 \mathrm{~B}$ \\
\hline \multirow[t]{3}{*}{5} & D-06052 & $2596 \mathrm{~b}$ & $2890 \mathrm{a}$ & $2743 \mathrm{~A}$ & 218.0 & 228.0 & $223.0 \mathrm{~A}$ \\
\hline & Mean & $2194 \mathrm{~B}$ & $2359 \mathrm{~A}$ & & 204.8 & $214.8 \mathrm{NS}$ & \\
\hline & $\begin{array}{l}\% \text { increase } \\
\text { over control }\end{array}$ & & 7.5 & & & 1.9 & \\
\hline
\end{tabular}

LSD for variety $=78$, inoculation $=49.5$, for interaction $=110.7 \quad$ LSD for variety $=30$

Table 2 Effect of bacterial inoculations on the nodules and plant height of some advanced lines of Chickpea.

\begin{tabular}{|c|c|c|c|c|c|c|c|}
\hline \multirow[t]{2}{*}{ S. No. } & \multirow{2}{*}{$\begin{array}{l}\text { Variety/ } \\
\text { Lines }\end{array}$} & \multicolumn{3}{|c|}{ No. of nodules/plant } & \multicolumn{3}{|c|}{ Plant height (cm ) } \\
\hline & & Un-inoculated & Inoculated & Mean & Un-inoculated & Inoculated & Mean \\
\hline 1 & $\mathrm{~Pb}-2008$ & $12.6 \mathrm{~b}$ & $16.1 \mathrm{a}$ & $14.4 \mathrm{~A}$ & 49.1 & 49.6 & $49.4 \mathrm{BC}$ \\
\hline 2 & D-03009 & $8.5 \mathrm{~h}$ & $10.8 \mathrm{de}$ & $9.6 \mathrm{D}$ & 47.0 & 49.1 & $48.1 \mathrm{C}$ \\
\hline 3 & D-06002 & $11.9 \mathrm{bc}$ & $12.4 \mathrm{~b}$ & $12.1 \mathrm{~B}$ & 47.0 & 48.4 & $47.7 \mathrm{C}$ \\
\hline 4 & D-06003 & $9.0 \mathrm{gh}$ & $10.1 \mathrm{de}$ & $9.6 \mathrm{D}$ & 50.1 & 53.0 & $51.5 \mathrm{~B}$ \\
\hline \multirow[t]{4}{*}{5} & D-06052 & $9.5 \mathrm{fg}$ & $11.2 \mathrm{~cd}$ & $10.3 \mathrm{C}$ & 55.8 & 59.1 & $57.4 \mathrm{~A}$ \\
\hline & Mean & $10.3 \mathrm{~B}$ & $12.1 \mathrm{~A}$ & & $49.8 \mathrm{~B}$ & $51.8 \mathrm{~A}$ & \\
\hline & $\%$ increase & & 17.5 & & & 4.0 & \\
\hline & over control & & & & & & \\
\hline
\end{tabular}

Table 3 Effect of bacterial inoculation on number of pods and branches of some advanced lines of Chickpea.

\begin{tabular}{cccccccc}
\hline S. No. & Variety/ & \multicolumn{3}{c}{ Pods/plant } & \multicolumn{3}{c}{ Branches/plant } \\
\cline { 3 - 7 } & Lines & Un-inoculated & Inoculated & Mean & Un-inoculated & Inoculated & Mean \\
\hline 1 & Pb-2008 & 54 & 64 & $59 \mathrm{D}$ & $6.0 \mathrm{ab}$ & $5.4 \mathrm{~cd}$ & $5.7 \mathrm{~A}$ \\
2 & $\mathrm{D}-03009$ & 81 & 86 & $83 \mathrm{~B}$ & $4.3 \mathrm{f}$ & $6.3 \mathrm{a}$ & $5.3 \mathrm{~A}$ \\
3 & $\mathrm{D}-06002$ & 77 & 86 & $82 \mathrm{~B}$ & $4.7 \mathrm{ef}$ & $5.0 \mathrm{de}$ & $4.8 \mathrm{~B}$ \\
4 & $\mathrm{D}-06003$ & 61 & 68 & $64 \mathrm{C}$ & $5.6 \mathrm{bc}$ & $5.1 \mathrm{cde}$ & $5.3 \mathrm{~A}$ \\
5 & D-06052 & 101 & 108 & $105 \mathrm{~A}$ & $5.4 \mathrm{~cd}$ & $5.5 \mathrm{bcd}$ & $5.4 \mathrm{~A}$ \\
& Mean & $75 \mathrm{~B}$ & $82 \mathrm{~A}$ & & 5.2 & $5.5 \mathrm{NS}$ & \\
& \% increase & & 9.3 & & & 5.8
\end{tabular}

over control

and four advanced lines (D-03009, D-06002, D-06003 and D-06052) of chickpea (Cicer arietinum) were used. Prepared seed inoculum (consisting of Mesorhizobium, Bacillus and Pseudomonas spp.each @ 10 $\left.5-10^{6} \mathrm{cfu} / \mathrm{g}\right)$ were collected from Soil Bacteriology Section, Ayub Agricultural Research Institute, Faisalabad. Seeds were inoculated by hand mixing of inoculum with seed @ one packet of inoculum per acre. The experimental area was divided into two sub plots (one for inoculated and other for un-inoculated seed). One set of seeds was sown after inoculation while other set of seeds was sown without inoculation as control. Nodules were collected/ counted at flowering and at maturity, five plants from each replication of each treatment were selected randomly and observations regarding the plant height, number of branches, number of pods, and 1000 grain weight were recorded. Grain yield was recorded after harvesting whole plot. Grain samples were collected for protein, fat, fiber, ash and carbohydrate analysis. Standard methods given in AOAC (2000) were followed to analyze quality parameters mentioned above. Data for three years were pooled and results are given and discussed as an average of three years data. Data were 
subjected to statistical analysis and means were compared using LSD test at 0.05 level of probability Steel et al. (1997).

\section{Results and Discussion Grain yield}

Bacterial inoculation significantly enhanced (7.5\%) the grain yield over non-inoculation (Table 1). The interactions between inoculation and Advanced lines were significant. Difference among the variety/Advanced lines was also significant. Advance line D-06052 gave the highest grain yield $(2743 \mathrm{~kg}$ ha $\left.{ }^{1}\right)$ while D-03009 gave the lowest grain yield $(2028 \mathrm{~kg}$ $\left.\mathrm{ha}^{-1}\right)$. The highest grain yield $\left(2890 \mathrm{~kg} \mathrm{ha}^{-1}\right)$ was recorded in inoculated Advanced line D-06052 while the lowest (1944 kg ha $\left.{ }^{-1}\right)$ in the un-inoculated chickpea Advanced line D-03009. Akhtar and Siddiqui (2009), Bhuiyan et al. (2008), Giri et al. (2010), Sarma et al. (2009) and Zahir et al. (2010) reported an increase in yield with microbial inoculation. Similar results were recorded by Gupta and Namdeo (1997).

Bacterial inoculation increased the nodulation and hence yield increased due to the enhanced availability of nitrogen. Similar results were obtained by Wani et al. (2007). Tena et al. (2016) also reported that inoculation had a pronounced effect on grain yield of chick pea.

\section{0 grain weight}

Results in table 1 showed that bacterial inoculation had no significant effect on 1000 grain weight. The check variety $\mathrm{Pb}-2008$ was statistically at par with advanced line D-06052 and differed significantly from the other advanced lines which had non-significant differences among themselves. Interaction among the inoculation and variety/advanced lines was also nonsignificant. The results are more or less similar to the findings of Bhuiyan et al. (2009) who quoted nonsignificant differences in 100 grain weight among chickpea genotypes and bacterial inoculation during the first year and reported a significant difference during the $2^{\text {nd }}$ year. The highest 1000 grain weight $(229.0 \mathrm{~g})$ was observed in inoculated check variety $\mathrm{Pb}-2008$ while the lowest 1000 grain weight $(188.5 \mathrm{~g})$ was found in un-inoculated advanced line D-06002.

\section{Number of nodules}

A significant effect of bacterial inoculation on nodulation was observed (Table-2). Variety/advanced lines differed significantly from one another. The highest number of nodules per plant (14.4) was observed in the check variety $\mathrm{Pb}-2008$. The interaction among variety /advanced lines and inoculation were also found significant. Maximum number of nodules per plant (16.1) was found in the inoculated variety $\mathrm{Pb}$ 2008. These findings are supported by the results of Akhtar and Siddiqi (2009), who found an increase in number of nodules in chickpea by bacterial inoculation.

\section{Plant height}

Results in table -2 showed that bacterial inoculation significantly increased the plant height. Maximum plant height $(59.1 \mathrm{~cm})$ was found with bacterial inoculation in advanced line D-06052 which was $16.9 \%$ higher than uninoculated check variety $\mathrm{Pb}-2008$. The results are in line with the findings of Akhtar and Siddiqi (2009) who reported that inoculation of chickpea with Rhizobium spp. caused a significant increase in growth, yield and number of nodules per root system as compared to no inoculation under field conditions. The increase in plant height may be attributed to the symbiotic nitrogen fixation, release of plant nutrients and growth hormones due to microbial activity.

\section{Number of pods per plant}

The data in table 3 showed that bacterial inoculation significantly improved the number of pods per plant $(9.33 \%)$ but interaction of advanced lines with bacterial inoculation were non-significant. The highest number of pods per plant (108) was observed in the inoculated advanced line D-06052 and the lowest number of pods per plant (54) was found in variety $\mathrm{Pb}$ 2008 without inoculation. Sarma et al. (2009) and Namvar and Shariff (2011) also reported a significant increase in number of pods per plant with microbial inoculation to chickpea.

\section{Number of branches per plant}

The response of different variety/advanced lines to bacterial inoculation was found inconsistent (Table 3). Overall effect of inoculation on branches per plant was nonsignificant. Bacterial inoculation significantly increased the number of branches only in the advanced line D-03009. Previous studies of Javad (2006) and Khan et al. (2006) confirm this statement which state that the response of legumes to microbial application is highly variable ranging from significantly negative to significantly positive. Climate variations also have large impact on the effectiveness of applied bacterial strains (Zaidi et al., 2009).

\section{Protein contents and protein yield}

Results revealed that bacterial inoculation did not affect the protein contents as well as total protein yield 
which were observed statistically at par with un-inoculated plants (Table 4). Among the advanced lines, line D-06052 was recorded in the advanced line D-03009 with inoculation and $303 \mathrm{~kg} \mathrm{ha}^{-1}$ protein by the variety $\mathrm{Pb}-2008$ without

Table 4 Effect of bacterial inoculation on protein contents and protein yield of some advanced lines of Chickpea.

\begin{tabular}{|c|c|c|c|c|c|c|c|}
\hline \multirow[t]{2}{*}{ S. No. } & \multirow{2}{*}{$\begin{array}{c}\text { Variety/ } \\
\text { Lines }\end{array}$} & \multicolumn{3}{|c|}{ Crude protein $(\%)$} & \multicolumn{3}{|c|}{ Protein yield $\left(\mathrm{kg} \mathrm{ha}^{-1}\right)$} \\
\hline & & Un-inoculated & Inoculated & Mean & Un-inoculated & Inoculated & Mean \\
\hline 1 & $\mathrm{~Pb}-2008$ & $19.0 \mathrm{~b}$ & $17.8 \mathrm{c}$ & $18.4 \mathrm{C}$ & $303 \mathrm{~b}$ & $350 \mathrm{ab}$ & $327 \mathrm{~B}$ \\
\hline 2 & D-03009 & $19.8 \mathrm{ab}$ & $17.2 \mathrm{c}$ & $18.5 \mathrm{C}$ & $352 \mathrm{ab}$ & $345 \mathrm{ab}$ & $348 \mathrm{AB}$ \\
\hline 3 & D-06002 & $19.2 \mathrm{~b}$ & $19.6 \mathrm{~b}$ & $19.4 \mathrm{~B}$ & $383 \mathrm{ab}$ & $375 a b$ & $379 \mathrm{AB}$ \\
\hline 4 & D-06003 & $19.4 \mathrm{~b}$ & $17.7 \mathrm{c}$ & $18.5 \mathrm{C}$ & $444 \mathrm{ab}$ & $451 \mathrm{a}$ & $448 \mathrm{~A}$ \\
\hline \multirow[t]{4}{*}{5} & D-06052 & $19.9 \mathrm{ab}$ & $20.7 \mathrm{ab}$ & $20.3 \mathrm{~A}$ & $373 a b$ & $428 \mathrm{ab}$ & $401 \mathrm{AB}$ \\
\hline & Mean & $19.6 \mathrm{NS}$ & 18.60 & & $371 \mathrm{NS}$ & 390 & \\
\hline & $\begin{array}{l}\% \text { increase } \\
\text { over control }\end{array}$ & & -8.2 & & & 5.1 & \\
\hline & \multicolumn{4}{|c|}{ LSD for variety $=0.76$, for interaction $=1.07$} & \multicolumn{3}{|c|}{ LSD for variety $=92.5$, for interaction $=130.8$} \\
\hline
\end{tabular}

Table 5 Effect of bacterial inoculation on carbohydrates and crude fat of some advanced lines of Chickpea.

\begin{tabular}{|c|c|c|c|c|c|c|c|}
\hline \multirow[t]{2}{*}{ S. No. } & \multirow{2}{*}{$\begin{array}{l}\text { Variety/ } \\
\text { Lines }\end{array}$} & \multicolumn{3}{|c|}{ Carbohydrates (\%) } & \multicolumn{3}{|c|}{ Fat $(\%)$} \\
\hline & & Un-inoculated & Inoculated & Mean & Un-inoculated & Inoculated & Mean \\
\hline 1 & $\mathrm{~Pb}-2008$ & $71.64 \mathrm{ab}$ & $69.96 \mathrm{cde}$ & $70.80 \mathrm{AB}$ & $3.62 \mathrm{~g}$ & $3.97 \mathrm{efg}$ & $3.80 \mathrm{D}$ \\
\hline 2 & D-03009 & $69.97 \mathrm{cde}$ & $71.90 \mathrm{a}$ & $70.93 \mathrm{AB}$ & 4.13 cdef & $4.39 \mathrm{abcd}$ & 4.26 AB \\
\hline 3 & D-06002 & $70.41 \mathrm{bcd}$ & $69.38 \mathrm{de}$ & $69.90 \mathrm{~B}$ & $4.04 \mathrm{def}$ & $4.74 \mathrm{a}$ & $4.39 \mathrm{AB}$ \\
\hline 4 & D-06003 & 69.09 ef & $71.23 \mathrm{abc}$ & $70.16 \mathrm{~B}$ & $4.70 \mathrm{ab}$ & $4.48 \mathrm{abc}$ & $4.59 \mathrm{~A}$ \\
\hline \multirow[t]{3}{*}{5} & D-06052 & $69.51 \mathrm{de}$ & $67.88 \mathrm{f}$ & $68.70 \mathrm{C}$ & $3.79 \mathrm{fg}$ & 4.33 bcde & $4.06 \mathrm{CD}$ \\
\hline & Mean & 70.12 & $70.10 \mathrm{NS}$ & & $4.06 \mathrm{~B}$ & $4.38 \mathrm{~A}$ & \\
\hline & $\begin{array}{l}\% \text { increase } \\
\text { over control }\end{array}$ & & 0.0 & & & 7.9 & \\
\hline
\end{tabular}

LSD for variety $=1.00$, for interaction $=1.421$

LSD for variety $=0.273$, inoculation $=0.173$, for interaction $=0.386$

responded to bacterial inoculation prominently with $20.7 \%$ protein contents against $19.9 \%$ protein contents in noninoculated plants of same advanced line. The highest protein contents $(20.7 \%)$ was produced by the same advanced line (D-06052) as compared to others 3 advanced lines and a variety $\mathrm{Pb}-2008$ while minimum protein contents (17. $2 \%$ ) was observed in the advanced line D3009. The results of present study are contradictory to the results of Aslam et al. (2010), Tahir et al. (2011), Ekhlas et al. (2011), Bejandi et al. (2012), Rugheim and Abdelgani (2012) and Abdalla et al. (2013) who reported higher protein contents due to the rhizobium inoculation to chickpea.

In case of total protein yield, the advanced line D-06003 proved better as compared to check variety $\mathrm{Pb}-2008$ and other advanced lines. This advanced line yielded $451 \mathrm{~kg} \mathrm{ha}^{-1}$ protein with inoculation and $444 \mathrm{~kg} \mathrm{ha}^{-1}$ protein without inoculation while the lowest protein yield ( $\left(345 \mathrm{~kg} \mathrm{ha}^{-1}\right)$ inoculation. Grain yield increased with the application of microbial inoculation but total protein yield did not increase accordingly due to lower protein contents in inoculated plant.

\section{Carbohydrates and fat}

There was no significant effect observed on carbohydrates and fat contents due to the application of bacterial inoculum to chickpea (Table 5). The highest carbohydrate contents $(71.90 \%)$ were observed in advanced line D-03009 while the lowest carbohydrate contents $(69.09 \%)$ were found in advanced line D-06003. When means for variety/lines were compared, advanced lines D03009, D- 06002, D-06003 and variety Pb-2008 were found statistically at par among themselves while the advanced line D-06052 ranked at the lowest position. Ekhlas et al (2011) found that Bradyrhizobium inoculation decreased the carbohydrate contents in cowpeas while Rugheim and Abdelgani (2012) found a decrease of carbohydrate in faba bean with Rhizobium inoculation. On the other hand, 
Senthikumar and Sivagurunathan (2012) found that Rhizobium inoculation increased the carbohydrates in green gram.

Bacterial inoculation significantly increased fat contents in chickpea (Table 5). The highest fat contents $(4.74 \%)$ was observed in advanced line D- 06002 with inoculation and $4.04 \%$ fat contents without inoculation while the lowest fat contents $(3.97 \%)$ was found in variety $\mathrm{Pb}-2008$ with inoculation and $3.6 \%$ fat contents without inoculation. On comparing the means for advanced fiber contents. In contrast to the results of this study, many researchers found an increase in crude fiber and ash contents of chickpea by rhizobium inoculation (Ekhlas et at. (2011), Rugheim and Abdelgani (2012), Abdalla et al. (2013) and Singh et al. (2014).

\section{Conclusion}

Responses of different genotypes of chickpea with respect to yield and its components and quality parameters varied to bacterial inoculation. Bacterial inoculation

Table 6 Effect of bacterial inoculation on crude fiber and ash contents of some advanced lines of Chickpea.

\begin{tabular}{cccccccc}
\hline S. No. & Variety/Lines & \multicolumn{3}{c}{ Crude fiber (\%) } & \multicolumn{3}{c}{ Ash (\%) } \\
\cline { 3 - 7 } & & Un-inoculated & Inoculated & Mean & Un-inoculated & Inoculated & Mean \\
\hline 1 & Pb-2008 & $3.84 \mathrm{ab}$ & $3.91 \mathrm{a}$ & $3.88 \mathrm{~A}$ & $3.10 \mathrm{ab}$ & $3.16 \mathrm{ab}$ & $3.13 \mathrm{AB}$ \\
2 & $\mathrm{D}-03009$ & $3.22 \mathrm{cde}$ & $3.35 \mathrm{bcde}$ & $3.28 \mathrm{CD}$ & $3.33 \mathrm{a}$ & $3.38 \mathrm{a}$ & $3.35 \mathrm{~A}$ \\
3 & $\mathrm{D}-06002$ & $3.00 \mathrm{de}$ & $2.90 \mathrm{e}$ & $2.95 \mathrm{D}$ & $3.00 \mathrm{ab}$ & $3.21 \mathrm{ab}$ & $3.10 \mathrm{AB}$ \\
4 & $\mathrm{D}-06003$ & $3.51 \mathrm{abcd}$ & $3.38 \mathrm{bcde}$ & $3.44 \mathrm{BC}$ & $3.16 \mathrm{ab}$ & $3.09 \mathrm{ab}$ & $3.12 \mathrm{AB}$ \\
5 & $\mathrm{D}-06052$ & $3.62 \mathrm{abc}$ & $4.00 \mathrm{a}$ & $3.81 \mathrm{AB}$ & $3.24 \mathrm{ab}$ & $3.16 \mathrm{ab}$ & $3.20 \mathrm{~B}$ \\
& Mean & 3.43 & $3.51 \mathrm{NS}$ & & 3.17 & $3.20 \mathrm{NS}$ & 0.95 \\
& \% increase over & & 2.3 & & & & \\
& control & & & & & & \\
\hline
\end{tabular}
LSD for variety $=0.37$, for interaction $=0.5252$ LSD for variety $=0.363$, for interaction $=0.513$

lines/variety, it was found that the advanced lines D-06002, D-06003 and D- 03009 were statistically at par but better than the advanced line $\mathrm{D}-06052$ and variety $\mathrm{Pb}-2008$. Fat contents in advanced lines D-06052 and D-06002 were significantly improved with inoculation. Results of present study are supported by Rugheim and Abdelgani (2012) who reported an increase in fat contents of faba bean with Rhizobium inoculation.

\section{Crude fiber and ash}

Bacterial inoculation did not affect the crude fiber and ash contents in chick pea (Table 6). The highest fiber content $(4.0 \%)$ was found in advanced line D-06052 with inoculation. On the other hand, the lowest value of crude fiber $(2.90 \%)$ was recorded in advanced line D-06002 with inoculation. When means for lines/variety were compared, it was observed that performance of variety $\mathrm{Pb}-2008$ was the best but it was statistically at par with advanced line D06052. The advanced line D- 06002 ranked at the lowest position (Table 6). Ash contents found in all the four advanced lines and a variety were statistically at par among themselves. When means for advanced lines/variety were compared, it was found that all the advanced lines were statistically at par however; advanced line D-03009 produced the highest ash contents (3.38 and $3.33 \%$ with and without inoculation respectively). In agreement with our results, Elsheikh et al. (2009) reported that inoculation with Bradyrhizobium to soybean had no significant effect on significantly increased the grain yield, plant height, nodulation, pods per plant and fat contents while 1000 grain weight, protein, carbohydrate, crude fat, crude fiber and ash contents, remained unaffected. On the basis of findings of present study it is recommended to inoculate chickpea seed with bacterial inoculation (Mesorhizobium ciceri, Pseudomonas spp. and Bacillus spp.) for cropping a good yield.

\section{References}

Abdalla, A.S., M.E. Abdelgani and A.G. Osman. 2013. Effect on biochemical and mineral fertilization on yield, chemical composition and physical characteristics of chickpea (Cicer arietinum L.) seeds. Pakistan Journal of Nutrition 12(1): 01-07.

Ahmed, Z.I., M. Tariq and M.S. Anjum. 2008. Effect of Rhizobium inoculation methods on performance of lentil in pothowar region. International Journal of Agriculture and Biology 10: 81-84.

Akhtar, M.S. and Z.A. Siddiqui. 2009. Use of plant growth promoting rhizobactaria for the biocontrol of root rots disease complex of chickpea. Australian Plant Pathology 38 (1): 44-50.

AOAC. 2000. Official Methods of Analysis of AOAC international. $17^{\text {th }}$ Ed. Vol. 1. William Horwitz, Gaithers Burg, M.D., USA.

Aslam, M., H.K. Ahmad, Himayatullah, M. Ayaz, E. Ahmad, A.G. Sagoo, Inayatullah, A. Hussain and M. Manzor. 
2010. Nodulation, grain yield and grain protein contents as affected by rhizobium inoculation and fertilizer placement in chickpea cultivar Bittle-98. Sarhad Journal of Agriculture 26(4): 467-475.

Bejandi, K.T., R.S. Sharifii, M. Sedghi and A. Namvar. 2012. Effect of plant density, rhizobium inoculation and micronutrients on nodulation, chlorophyll content and yield of chickpea (Cicer arietinum L.). Annals of Biological Research 3(2): 951-958.

Bhuiyan, M.A.H., D. Khanam, M.F. Hossain and M.S. Ahmad. 2008. Effect of rhizobial inoculation on nodulation and yield of chick pea in calcareous soil. Bangladash Journal of Agriculture Research 33 (3): 549-554.

Bhuiyan, M.A.H., D. Khanam, M.H. Ullah and M.M. Alam. 2009. Effect of inoculation and varietal interactions of chickpea at southern region of Bangladesh. Bulletin Institute Tropical Agriculture. Kyushu University. 32: $17-23$

Ekhlas, M.M., E.A.E. Elsheikh, I.A.M. Ahmed and E.E. Babeker. 2011. Effect of inter cropping, Bradyrhizobium inoculation and N, P fertilizers on yield, physical and chemical quality of cowpea seed. Frontier Agriculture China 5(4): 543-551.

Elliott, D.E. and R.J. Abbott. 2003. Nitrogen fertilizer use on rain-fed pasture in the Mt. Lofty Ranges. 1. Pasture mass, composition and nutritive characteristics. Australian Journal of Experimental Agriculture 43: 553577.

Elsheikh, E.A.E., S.S.M. Salih, A.A. Elhussein and E.E. Babiker. 2009. Effect of intercropping, Bradyrhizobium inoculation and chicken manure fertilization on the chemical composition and physical characteristics of soybean seed. Food Chemistry 112(3): 690-694.

Giri, N. and N.C. Joshi. 2010. Growth and yield response of chick pea (Cicer arietinum L.) to seed inoculation with rhizobium sp. Nature and Science 8 (9): 232-236.

Government of Pakistan. 2014. Pakistan Bureau of Statistics. Ministry of Food and Agriculture, Islamabad, Pakistan.

Gupta and S.L. Namdeo. 1997. Effect of Rrhizobium, phosphate solubilizing bacteria and FYM on nodulation, grain and quality of chick pea. Indian Journal of Pulses Research 10: 171-174.

Huisman, J. and A.F.V. Poel. Aspect of the nutritional quality and use of cool season food legumes in animal feed. In: Expanding the Production and use of Cool Season Legume. F.J. Muehlbauer and W. J. Kaiser (eds.). Dordrecht: Kluwer Academic publishers.

Javad, A. 2006. Foliar application of effective microorganisms as an alternative fertilizer for pea. Agronomy for Sustainable Development 26: 257-363.

Javed, A. and R. Bajwa. 2011. Field evaluation of effective microorganisms (EM) application for growth, nodulation and nutrition of mung bean. Turkish Journal of Agriculture 35: 1-10.

Khan, B.M., M.K. Hussain and M.A.U. Mridha. 2006. Effect of microbial inoculants on Albizia saman germination and seedling growth. Journal of Forest Research. 17: 99-102.

Mehboob, I, Z.A. Zahir, A. Mahboob, S.M. Shahzad, A. Jawad and M. Arshad. 2008. Preliminary screening of rhizobium isolates for improving growth of maize seedling under axenic conditions. Soil and Environment 27:64-71.

Namvar, A. and R.S. Shariff. 2011. Phenomse of chick pea (Cicer arietinum L.) to symbiotic and mineral nitrogen fertilization. Zemdir byste + Agriculture 98:121-130.

Rewari, R.B. and T. Nkvbr. 1988. Microbiology of pulse crops, Oxford and IBH, New Delhi. Edited by Balder B, Remanijam JS, Jain HK. 373-411.

Romdhane, S.B., M.E. Aouani, M. Trabelsi, P. deLajudie, and R. Mhamdi. 2008. Selection of high nitrogen-fixing rhizobia nodulating chickpea (Cicer arietinum) for semiarid Tunisia. Journal of Agronomy and Crop Science 194 (6): 413-420.

Rugheim, A.M.E. and M.E. Abdelgani. 2012. Effect of microbial and chemical fertilization on yield and seed quality of faba bean (Vicia faba). International Food Research Journal 19(2): 417-422.

Sarma, M.V.R. K., K. Saharan, A. Prakash, V.S. Bisaria and V. Sahai. 2009. Application of Fluorescent Pseudomonads inoculant formulations on Vigna mungo through field trial. World Academy of Science, Engineering and Technology 51: 789-793.

Senthikumar, P.K and P.S., Sivagurunathan. 2012. Comparative effect on bacterial biofertilizer on growth and yield of green gram (Phaseolus radiata L.) and cowpea (Vigna siensis). International Journal of Current Microbiology and Applied Science 1(1): 34-39

Singh, H., P. Singh, R.P. Singh and M. Tripathi. 2014. Biochemical and molecular studies on rhizobium inoculated chickpea (Cicer arietinum L.) genotype grown in Eastern UP. American Journal of Biochemistry and Molecular Biology. DOI 0.3923/ajbmb.2014.

Steel, R.G.D., J.H. Torrie and D.A. Deekey, 1997. Principals and Procedures of Statistics: A biometrical approach. $3^{\text {rd }}$ Ed. Mc Graw Hill Book Co., Inc. New York. 400-428 p.

Tahir, M., A. Ali, N. Aabidin, M. Yaseen and H. Rehman. 2011. Effect of Molybdenum and seed inoculation on growth, yield and quality of mung bean. Crop and Environment 2(2): 37-40.

Tena, W., E.W. Meskel and F. Walley. 2016. Response of chickpea (Cicer arietinum L.) to inoculation with native and exotic Mesorhizobium strains in Southern Ethiopia. African Journal of Biotechnology 15(35): 1920-1929. DOI:10.5897/AJB2015.15060. 
Tilak, K.V.B.R. 1993. Bacterial Fertilizers, Indian Council of Agricultural Research, New Dehli, India, 4-33.

Wani, P.A., M.S. Khan and A. Zaidi. 2007. Synergistic effects of the inoculation with nitrogen-fixing and phosphate solubilizing rhizobacteria on the performance of field grown chickpea. Journal of Plant Nutrition and Soil Science 170 (2): 283-287

Zahir, Z.A., M.H. Yasin, M. Naveed, M.A. Anjum and M.Khalid. 2010. L Tryptophan application enhances the effectiveness of Rhizobium inoculation for improving growth and yield of mung bean (Vigna radiata). Pakistan Journal of Botany 42(3):1771-1780.
Zaidi, A., M.S. Khan, M. Ahmad and M. Oves. 2009. Plant growth promotion by phosphate solubilizing bacteria. Acta Microbiology and Immunology 56: 263-284 